\title{
PENDIDIKAN KEAKSARAAN DI INDONESIA KE DEPAN
}

\author{
W. P. Napitupulu*
}

\begin{abstract}
Quoting EFA Global Monitoring Report 2006 on literacy for life, this article discusses its implementation in Indonesia. It is believed that the success of the literacy program is closely related to the government policy. Based on the analysis of the condition and problems of illiteracy, the political leaders of the highest level are expected to be committed to take real actions, all nations including Indonesia formulate and implement written and explicit literacy policy in developing access to basic education, conduct continuous literacy program. In conclusion, the article suggests the Indonesian Government, as a member of United Nations, should tightly keep the commitment expressed in a number of UN's declarations and conferences including to achieve the goals in The United Nations Literacy Decade 2003-2012.
\end{abstract}

Key words: literacy, education for all, literacy for life, lifelong learning.

\section{PENDAHULUAN}

Pada perayaan Hari Natal dan Tahun Baru 2006 yang diselenggarakan oleh KORPRI Departemen Pendidikan Nasional pada hari Jumat, 13 Januari 2006 di Plaza Depdiknas, Menteri Pendidikan Nasional, Bapak Prof. Dr. Bambang Sudibyo, menyatakan dengan tegas, bahwa yang buta huruf atau niraksara itu pada umumnya adalah yang keadaan ekonominya kurang menguntungkan alias miskin. Juga ditegaskan bahwa upaya yang harus dijalankan adalah dua-duanya, yakni serentak memberantas keniraksaraan dan kemiskinan. Judul Education For All (EFA) Global Monitoring Report 2006 adalah Literacy for Life
(Keaksaraan untuk Kehidupan) yang pada hakikatnya diungkapkan oleh sikap dan pernyataan Menteri tersebut di atas dan yang harus dijadikan pedoman di dalam upaya pendidikan keaksaraan Indonesia ke depan. EFA Global Monitoring Report 2006 memberikan laporan tentang keadaan keaksaraan yang perlu mendapat perhatian serta memberikan rekomendasi kebijakan yang perlu ditempuh oleh masing-masing Negara. Berikut ini dibahas tentang keaksaraan dan rekomendasi kebijakan yang disebutkan dalam naskah EFA Global Monitoring Report 2006 itu.

\section{PEMBAHASAN}

Lebih terperinci EFA Global Monitoring Report 2006 mengemukakan, bahwa keaksaraan: ${ }^{1}$

\section{Adalah hak yang masih diingkari bagi hampir} seperlima penduduk orang-orang dewasa di dunia ini.

Sepuluh persen dari penduduk orang dewasa di Indonesia yang niraksara adalah sebagian dari penduduk dunia yang seperlima itu. Ini berarti bahwa ke depan bukan hanya perhatian tetapi terutama program yang relevan harus disusun, direncanakan, dan dilaksanakan untuk kepentingan penduduk Indonesia yang niraksara dan miskin ini. Dengan perkataan lain, segala upaya hendaklah dicari yang membuat program keaksaraan menjadi benar-benar hak setiap orang untuk diembannya, baik yang dilaksanakan melalui jalur pendidikan sekolah (formal) maupun jalur pendidikan luar sekolah (nonformal) dan pembelajaran informal. Jika upaya itu dijalankan dengan sungguh-sungguh dengan peranserta semua pihak, maka bukanlah suatu hal yang mustahil bahwa Indonesia benar-benar bebas buta huruf atau niraksara menjelang tahun 2015.

\section{Adalah sangat perlu untuk dapat meraih setiap tujuan Pendidikan untuk Semua (PUS) atau Education for All - EFA.}

Ke depan Indonesia perlu memberi makna yang sungguh-sungguh tentang keaksaraan dan kaitannya yang erat dengan setiap tujuan yang tercantum di dalam 
tujuan-tujuan PUS Dakar. Jadi janganlah perhatian hanya ditujukan pada pencapaian $50 \%$ perbaikan dalam tingkat keniraksaraan orang dewasa menjelang tahun 2015. Alangkah indahnya jika Indonesia memberanikan diri menjadikan PUS menjadi program utama Departemen Pendidikan Nasional sampai tahun 2015. Jika hal itu tidak dapat dilakukan, maka pelaksanaan Wajib Belajar Pendidikan Dasar 9 tahun (6 tahun sekolah dasar dan 3 tahun sekolah menengah pertama) yang dijadikan program utama sekarang ini hendaklah benar-benar berarti bahwa sasarannya bukan hanya anak dan remaja berusia 7 sampai 15 tahun (yang pada hakikatnya menjadi tanggung jawab utama Direktorat Jenderal Pendidikan Dasar dan Menengah, yang sekarang bernama Direktorat Jenderal Manajemen Pendidikan Dasar dan Menengah) akan tetapi di luar itu adalah juga mereka yang berusia 16 tahun ke atas yang belum berpendidikan dasar. Ini tentu menjadi tanggung jawab Direktorat Jenderal Pendidikan Luar Sekolah (sekarang ini bernama Direktorat Jenderal Pendidikan Nonformal dan Informal) untuk memotivasi dan mengkoordinasi usaha Pemerintah dan swasta di bidang ini. Ini berarti bahwa program keaksaraan dalam rangka pelaksanaan Wajib Belajar Pendidikan Dasar 9 tahun untuk penduduk berusia 16 tahun ke atas meliputi: (1) mereka yang niraksara atau buta huruf, (2) mereka yang putus sekolah dasar, (3) mereka yang sudah tamat sekolah dasar atau Paket A, dan (4) mereka yang putus sekolah menengah pertama atau Paket B.

\section{Adalah suatu gejala masyarakat (kolektif) dan} perorangan dengan perhatian yang perlu ditujukan pada kedua dimensi itu.

Indonesia ke depan juga perlu memperhatikan dimensi yang dua ini, agar upaya pemberantasan keniraksaraan dan tentu juga kemiskinan serta keaksaraan melalui jalur pendidikan sekolah (formal) bukan hanya urusan perorangan akan tetapi adalah urusan masyarakat (bersama), karena manusia adalah serentak individu dan sosial yang keduanya tidak dapat dipisahkan. Ini juga dapat berarti, bahwa jika PUS akan berhasil maka diperlukan SUP (Semua Untuk Pendidikan atau All for Education-AFE). Semua untuk pendidikan berarti, bahwa setiap orang - terutama tenaga kerja terdidik-dan semua lembaga-bukan hanya yang bergerak di bidang pendidikan-perlu berperan serta untuk menyukseskan program keaksaraan khususnya dan program PUS umumnya. Jadi, disamping upaya untuk memotivasi orang-seorang agar berperan serta secara aktif-positif di dalam program keaksaraan, baik sebagai peserta didik maupun sebagai guru atau tutor, upaya motivasi perlu juga ditujukan terhadap berbagai lembaga yang ada di dalam masyarakat, baik lembaga pendidikan maupun lembaga sosial-ekonomi, sosialreligius, dan sosial-politik.

4. Adalah penting sekali untuk partisipasi dalam pembangunan ekonomi, sosial, dan politik, terutama di dalam masyarakat pengetahuan sekarang ini.

Di Indonesia, pada pemilihan Presiden dan Wakil Presiden serta Pemilihan Kepala Daerah mendatang sudah semakin jelas, bahwa keaksaraan memainkan peranan yang penting. Demikian pula usaha-usaha di bidang sosial-ekonomi di masa lalu dan terutama di masa depan akan lebih menuntut perlunya keaksaraan yang berkualitas yang dimiliki oleh setiap orang. Dulu memang pernah suatu pendapat dikemukakan, yaitu bahwa 'sebenarnya niraksarawan/wati tidak apa, biarlah tetap buta huruf asal jangan buta keterampilan yang dapat dijadikan bekal untuk mencari nafkah sesehari', namun sekarang di dalam 'ekonomi berbasis pengetahuan' (knowledge-based economy), pernyataan itu sudah diragukan kebenarannya, karena pendapat lain sudah diterima, bahwa manusia tidak hanya hidup untuk makan (seperti hewan), tetapi makan untuk hidup, dan keaksaraan untuk kehidupan, bukan hanya untuk 'keterampilan' atau 'perut'. Sekarang ini 'informasi' sudah menjadi barang dagangan (information is a commodity) dan siapa yang mempunyai informasi akan bergerak satu-dua langkah mendahului orang lain, dan kemampuan untuk mampu berbuat seperti itu adalah melalui penguasaan 'aksara, angka, dan berhitung' atau yang disebut sekarang dengan 'membaca, menulis dan berhitung', disingkat 'calistung' alias keaksaraan.

\section{Adalah kunci untuk meningkatkan kemampuan manusia yang meliputi banyak keuntungan, termasuk berpikir kritis, perbaikan perencanaan kesehatan dan keluarga, pencegahan HIV/AIDS ${ }^{2}$, pendidikan anak, pengurangan kemiskinan dan kewarga- negaraan yang aktif.}

Program keaksaraan di Indonesia di hari depan hendaklah memperhatikan keuntungan yang dikemukakan di atas ini. Ini berarti bahwa pengetahuan dan informasi yang relevan dengan hal-hal tersebut hendaklah termasuk di dalam bahan-bahan belajar keaksaraan, baik yang digunakan di lembaga pendidikan sekolah (formal) maupun luar sekolah (nonformal), termasuk di dalam bahan pembelajaran informal. Namun tekanan bukanlah terutama pada tersedianya bahan belajar-ini memang prioritas pertama-dan dikuasainya pengetahuan dan informasi yang tersedia di dalam bahan belajar itu, yaitu sendi atau pilar pendidikan pertama (learning to know, 
termasuk learning how to learn) akan tetapi yang penting juga adalah pelaksanaannya, yaitu sendi pendidikan ke dua (learning to do), di samping sendi yang dua lagi (empat sendi atau pilar pendidikan), yaitu belajar menjadi seseorang atau mendarahdagingkan informasi menjadi bagian kepribadian kita, jati diri kita (learning to be), dan belajar hidup bersama atau hidup dengan orang-orang lain (learning to live together, to live with others). ${ }^{3}$ Setiap program pendidikan hendaklah memperhatikan prinsip empat sendi atau pilar pendidikan yang menjadi dasar bagi pelaksanaan prinsip yang satu lagi, yakni pendidikan/belajar sepanjang hayat (lifelong education, lifelong learning).

Naskah EFA Global Monitoring Report 2006, Literacy for life itu juga mengemukakan bahwa tantangan keaksaraan hanya dapat dihadapi melalui dua buah kebijakan utama yang sekaligus ditanggapi dengan memperhatikan Indonesia ke depan, adalah sebagai berikut.

\section{Pemimpin-pemimpin politik di tingkat tertinggi} hendaklah berjanji (komitmen) kepada diri sendiri untuk melakukan tindakan.

Pemimpin politik dengan kekuasaan yang dipegangnya hendaklah menggunakan kekuasaan itu untuk kepentingan rakyat, terutama rakyat kecil yang tanpa bantuan pemimpin tidak akan mungkin bangkit sendiri. Pemimpin politik hendaklah menjadikan program keaksaraan prioritas pertama, sebab sebagaimana sudah diuraikan di atas, keaksaraan adalah untuk kehidupan (literacy for life). Sudah tidak zamannya lagi untuk berpegang pada sikap yang menyatakan, bahwa 'jika rakyat tetap bodoh maka akan lebih mudah memimpinnya'. Ini adalah sikap penjajah yang harus diusahakan untuk menjauhinya terus-menerus. Pada hakikatnya, di negara demokrasi, rakyat yang 'pintar' lebih mudah mengajaknya untuk bertukar pendapat dan mengajaknya untuk bergerak bersama ke tujuan bersama yang sudah ditetapkan terlebih dahulu, seperti masyarakat adil-makmur, material-spiritual berdasarkan Pancasila dan UndangUndang Dasar Negara Republik Indonesia 1945. Pemimpin hendaklah menjadikan dirinya manusia yang sangat mangkus atau efektif dengan mendarahdagingkan tujuh kebiasaan, namun tidak tinggal di situ tetapi bergerak melampaui efektivitas menggapai keagungan seperti yang dikemukakan oleh Stephen R. Covey.Pemimpin harus menjadi manusia panutan, perintis, penyelaras, dan pemberdaya. ${ }^{4}$
2. Negara-negara, termasuk Indonesia hendaklah memakai kebijakan keaksaraan secara tersurat atau eksplisit dengan tujuan sebagai berikut.

a. Memperluas pendidikan dasar (sekolah dasar dan sekolah menengah pertama) yang berkualitas.

Ini sejalan dengan program Wajib Belajar Pendidikan Dasar 9 tahun Indonesia, dan kata kunci di sini adalah 'berkualitas' yang memerlukan perhatian yang sungguh-sungguh dari kita semua. Memang tiada gunanya seseorang menamatkan sekolah menengah pertama, karena tidak dapat berbuat banyak. Dalam hubungan ini hendaklah anak yang belajar itu didekati dan diperlakukan sebagai manusia seutuhnya dengan ranah kognitif, afektif, dan psikomotorik yang dimilikinya. Dengan menggunakan istilah lain, hendaklah anak yang belajar itu didekati pada dua belahan otaknya, yakni belahan otak kiri atau berpikir vertikal (berpikir logis-sistematis-analisis) dan belahan otak kanan atau berpikir lateral (berpikir intuitif-kritissintesis). ${ }^{5}$

b. Meningkatkan program keaksaraan untuk pemuda dan orang dewasa. Untuk itu diperlukan hal-hal berikut.

1) Tanggung jawab Pemerintah yang aktif untuk kebijakan dan pembiayaan keaksaraan orang dewasa sebagai bagian dari rencana sektor pendidikan. Ini sudah dilaksanakan bertahun-tahun, tinggal upaya yang lebih kreatif untuk mampu bergerak ke keadaan Indonesia yang bebas buta huruf. Indonesia sudah memahami bahwa keaksaraan adalah hak dan merupakan kunci untuk hak-hak lain.

2) Kerangka yang jelas dalam mengkoordinasi penyediaan program keaksaraan oleh Pemerintah, swasta, dan masyarakat madani. Pada hakikatnya hal ini juga sudah dilaksanakan di Indonesia, namun perlu lebih ditingkatkan guna kemangkusan (efektivitas), kesangkilan (efisiensi) dan produktifitas program.

3) Peningkatan alokasi anggaran dan bantuan. Jika pemerintah bersungguh-sungguh maka bunyi undang-undang yang menyatakan $20 \%$ anggaran (RAPBN dan RAPBD) untuk pendidikan hendaklah segera dilaksanakan, 
dan tidak setengah hati, karena sikap setengah hati tidak akan membawa kemajuan. Prioritas pertama hendaklah diberikan pada peningkatan kualitas manusia, karena hanya jika kita berbuat demikian maka hasil berlipatgandanya akan diperoleh; ini tentu jika dibandingkan dengan benda mati seperti gedung, dan sebagainya.

4) Pengertian tentang permintaan/kebutuhan peserta didik, khususnya preferensi bahasa dan motivasi mereka untuk mengikuti kelas. Hal ini tentu dilakukan dengan berkonsultasi dengan komunitas setempat (lokal). Mengenai hal ini mungkin untuk ke depan, kita perlu memikirkan tata cara berbuat yang lebih baik. Di masa lalu, bahasa Ibu digunakan di kelas I dan II sekolah dasar. Khusus di jalur pendidikan luar sekolah memang sudah diberi perhatian, sehingga di Irian Jaya (sekarang Papua) umpamanya bekerjasama dengan SIL (Summer Institute of Linguistics) buku Paket A dipelajari sesudah pengenalan abjad dengan menggunakan bahasa setempat (yang banyak jumlahnya itu!), dan di Aceh (sekarang Nanggroe Aceh Darussalam) dimulai dengan tulisan Arab setempat sebelum ke Paket A yang menggunakan aksara Latin itu.

5) Kurikulum yang dibangun di atas permintaan/ kebutuhan ini dengan tujuan belajar yang jelas dan tersedianya bahan belajar yang memadai, baik untuk keperluan anak dan pemuda di sekolah maupun untuk keperluan orang dewasa di luar sekolah perlu segera diteliti, terutama bahan belajar untuk program keaksaraan di jalur pendidikan luar sekolah. Penelitian ini dianggap perlu, karena sejak tahun 1975 sudah ada Paket A versi Napitupulu, Paket A versi Soedijarto, mungkin Paket A versi Fasli Jalal, dan mungkin juga sudah ada versi yang paling baru. Diperlukan Paket A baru yang berisi pengetahuan dan informasi setara dengan sekolah dasar, sebagai pengganti Paket A-1 sampai dengan A-100 yang lama (1975), karena sesudah 30 tahun tentu ada pengetahuan dan informasi yang perlu diperbaharui disesuaikan dengan perkembangan zaman.

6) Pembayaran yang memadai, kedudukan profesional dan kesempatan pelatihan bagi para pendidik keaksaraan. (a) Pembayaran yang memadai memang merupakan masalah terberat, karena para guru di sekolah pun belum memperoleh upah atau gaji yang memadai. Katanya dengan Undang-undang Guru yang baru mudah-mudahan kesejahteraan guru akan meningkat. Namun untuk memperlakukan hal itu bagi para tutor di jalur pendidikan luar sekolah, masih sulit. Dalam hubungan ini mungkin sebaiknya kita tetap berpegang pada 'kesukarelaan' yang merupakan inti sistem sosial gotong-royong kita atau 'kesukarelaan plus'? Namun jika hal ini tidak sesuai lagi dengan pertumbuhan masyarakat (sudah mulai mata duitan yang dipicu oleh projek di masa lalu!), maka perlu dikaitkan gejala 'tersedianya para penganggur terdidik' dengan program keaksaraan yang memerlukan tenaga untuk melaksanakannya. (b) Tenaga kerja terdidik ini diberi kesempatan pelatihan yang memadai untuk menjadi guru atau pendidik keaksaraan, sehingga lambatlaun mereka memperoleh kedudukan professional.

7) Kebijakan bahasa yang tepat, karena pada umumnya hampir semua negara yang menghadapi tantangan keaksaraan memiliki bahasa yang beraneka ragam. Secara pedagogis penggunaan bahasa Ibu memang baik, namun harus ditawarkan suatu peralihan yang licin untuk kesempatan mempelajari bahasa kawasan dan bahasa resmi. Jika melalui pelaksanaan Program Kejar Paket A yang dulu dan sekarang sudah dapat dikemukakan, bahwa bahasa Indonesia penduduk sudah dapat diandalkan, maka proses pembelajaran bahasa daerah, terutama bagi mereka yang masih buta huruf dapat segera dilaksanakan, namun tidak boleh dilupakan bahasa Indonesia sebagai bahasa pemersatu kita. Sebenarnya makin banyak bahasa yang dikuasai oleh seseorang makin baik, dan ini bukan hanya bahasa modern tetapi juga bahasa daerah yang jumlahnya sangat banyak di Indonesia ini.

Kesimpulan yang tercantum dengan jelas di dalam EFA Global Monitoring Report 2006, Literacy for life itu adalah: "Memperoleh, memperbaiki dan menggunakan keterampilan keaksaraan terjadi di semua jenjang pendidikan, dan di dalam konteks ganda sekolah dan luar sekolah. Mencapai setiap tujuan PUS sangat tergantung pada kebijakan-kebijakan yang membantu perkembangan masyarakat yang bebas buta huruf dan menetapkan standar yang tinggi untuk keaksaraan sebagai fondasi pembelajaran lanjutan." 
Kesimpulan ini perlu direnungkan, dan semua program PUS, termasuk keaksaraan, baik yang terjadi di jalur pendidikan sekolah maupun luar sekolah perlu diarahkan pada semangat di atas, dimana ditegaskan, bahwa standar keaksaraan yang tinggi itulah fondasi pembelajaran lanjutan.

c. Mengembangkan lingkungan keaksaraan yang kaya dan masyarakat yang bebas buta huruf memerlukan perhatian yang berkelanjutan yang ditujukan terhadap hal-hal sebagai berikut.

1) Kebijakan bahasa.

Memang UNESCO sudah mempunyai kebijakan yang jelas mengenai bahasa yang menempatkan bahasa Ibu, bahasa resmi (nasional) dan bahasa asing pada tempat masing-masing secara proporsional. Seseorang tidaklah disuruh untuk hanya menguasai dan memahami bahasa Ibunya, tetapi juga bahasa resmi dan bahasa asing. Ini berarti, bahwa kebijakan yang ditentukan adalah agar setiap warga negara menguasai sedikitnya tiga bahasa (trilingual) yang memungkinkannya bergaul secara lokal, nasional dan internasional.

2) Kebijakan penerbitan buku.

Diperlukan kebijakan yang beragam di bidang penerbitan buku untuk keperluan berbagai lapisan masyarakat, terutama untuk membantu masyarakat yang kurang mampu membeli buku untuk dipelajarinya dalam rangka meningkatkan kualitasnya atau kualitas anak-anaknya. Penerbitan untuk keperluan program keaksaraan perlu mendapatkan prioritas pertama, agar mereka yang baru melek huruf (neoliterates) umpamanya terbantu dalam memelihara kemampuan 'calistungnya'. Pada tahun 19541959 mahasiswa diizinkan membeli bukubuku teks dengan harga murah dan ini sangat membantu mahasiswa yang memang masih sangat tergantung pada orangtuanya untuk membeli buku-buku yang sangat diperlukan itu. Memang ada cara lain, yakni dengan memperkuat perpustakaan dan menambah jumlah naskah yang sama, agar beberapa mahasiswa dapat sekaligus menggunakan buku yang sama. Perpustakaan ini tentu juga dapat dibantu oleh para penerbit dengan memasukkan beberapa buku ke dalamnya.

3) Kebijakan media.

Media juga perlu dimotivasi dan dikerahkan untuk berperan serta membina lingkungan keaksaraan yang mendorong setiap orang, mulai dari mereka yang baru melek huruf sampai mereka yang sudah di bangku perguruan tinggi termotivasi untuk meningkatkan mutu keaksaraannya. Media dapat umpamanya membuat rubrik khusus di surat kabar atau majalahnya untuk mereka yang baru melek huruf. Media dapat menyelenggarakan sayembara menulis menurut berbagai tingkatan yang mendorong orang memelihara dan meningkatkan mutu keaksaraannya.

4) Akses pada informasi.

Setiap orang hendaklah memperoleh akses pada informasi secara bebas, artinya tidak boleh seseorang dihalang-halangi, karena ini juga termasuk prinsip demokrasi dan hak asasi manusia. Akses pada informasi sebenarnya hanyalah sebagian kecil dari akses pada pendidikan. Pendidikan adalah usaha yang dijalankan dengan sengaja, teratur dan berencana dengan maksud mengubah tingkah-laku manusia ke arah yang diinginkan. ${ }^{6}$ Melalui pendidikan disampaikan hal sebagai berikut. (1) Pengetahuan dan informasi fungsional yang dapat digunakan untuk meningkatkan mutu dan taraf hidup. (2) Keterampilan yang relevan yang dapat digunakan sebagai bekal untuk mencari nafkah sehari-hari. (3) Ditanam, dipupuk dan dikembangkan sikap mental pembaharuan dan pembangunan. Akses pada informasi yang disebut di atas termasuk sebagian dari sasaran pertama pendidikan (pengetahuan dan informasi). Akses pada informasi ini tentu maksudnya adalah informasi tertulis, karena kita berbicara tentang keaksaraan. Sebenarnya masalah terbesar yang dihadapi adalah masalah budaya, artinya keaksaraan akan lebih maju di Indonesia ke depan, jika diusahakan terusmenerus menyeimbangkan 'kebudayaan lisan' dengan 'kebudayaan tulisan'.

5) Kebijakan untuk memasukkan buku dan bahan bacaan ke sekolah dan rumah.

Pada hakikatnya buku dan bahan bacaan wajar memasuki sekolah-sekolah, sehingga kebijakan ini lebih ditekankan pada kualitas dan kuantitas buku dan bahan bacaan yang dimasukkan ke sekolah dan pada kebijakan untuk membangun 'perpustakaan sekolah'. Di zaman dahulu ketika 'perpustakaan umum' 
belum berkembang, maka buku dan bahan bacaan lain dikumpulkan oleh orang-seorang di rumahnya, sehingga 'perpustakaan pribadi' berkembang amat pesat. Pada waktu itu tidak perlu diadakan kebijakan untuk memasukkan buku dan bahan bacaan ke rumah. Mungkin yang diperlukan adalah kebijakan tentang harga buku agar sedikitnya sekali sebulan seseorang mampu membeli buku dan bahan bacaan baru yang dimasukkan ke 'perpustakaan pribadi' di rumah. Terutama bagi mereka yang baru melek huruf perlu dibuat suatu kebijakan khusus mengenai harga bahan bacaan dan buku yang diperlukannya agar seseorang itu tidak kembali lagi menjadi buta huruf.

Lima hal di atas yang dikemukakan oleh EFA Global Monitoring Report 2006, Literacy for Life tentu dapat ditambah dengan kebijakan yang memperhatikan keadaan di Indonesia ini dalam rangka membangun lingkungan keaksaraan yang dinamis, seperti: (a) mengajak setiap orang untuk memberikan hadiah ulang tahun kepada teman atau kekasih berupa buku atau bahan bacaan lain akan mendorong berkembang dan mendalamnya keaksaraan di Indonesia; (b) meninggalkan kenang-kenangan berupa buku di sekolah yang ditinggalkan pada waktu tamat juga akan berdampak sama; dan (c) kegiatan di dalam kelas yang dulu dilaksanakan dengan sungguh-sungguh akan tetapi belakangan kurang diperhatikan adalah 'mengarang' dan ini dapat dimulai sejak taman kanakkanak dan kelas I sekolah dasar dalam bentuk gambargambar, sedangkan dengan aksara dapat dimulai sejak kelas II sekolah dasar.

\section{KESIMPULAN}

Indonesia sebagai anggota Perserikatan Bangsa-Bangsa (PBB) dan anggota UNESCO wajib berpegang teguh pada komitmen yang diungkapkan melalui berbagai deklarasi dan konferensi PBB. Hasilhasil yang diharapkan dari The United Nations Literacy Decade 2003-2012, ${ }^{7}$ seperti: (a) kemajuan yang signifikan menjelang tahun 2015 akan tujuan-tujuan 3 , 4, dan 5 Dakar, bertambahnya secara mutlak jumlah kaum perempuan yang melek huruf; (b) dicapainya oleh semua peserta didik suatu tingkat penguasaan pembelajaran dalam membaca, menulis, berhitung, berpikir kritis, nilai-nilai kewarganegaraan yang positif dan kecakapan hidup lain; (c) lingkungan keaksaraan yang dinamis, sehingga keaksaraan akan berlanjut dan diperluas di luar Dasawarsa Keaksaraan (Literacy Decade) tersebut; dan (d) perbaikan kualitas hidup (penurunan kemiskinan, pendapatan yang meningkat, perbaikan kesehatan, peran serta yang lebih besar, kesadaran kewarganegaraan dan kepekaan gender) di antara mereka yang berperan serta di dalam berbagai program PUS, agar dapat diwujudkan di Indonesia.

Sebenarnya sejak tahun 2000, yaitu Dakar EFA Goals, sudah ada komitmen internasional untuk membantu pelaksanaan PUS yang mangkus, sangkil dan produktif, namun pemanfaatan komitmen itu belum maksimal, karena kekurangmampuan negara-negara untuk menyusun program-program yang akan dilaksanakan. Pada waktu itu dengan tegas dikatakan, bahwa tidak ada satu negara pun yang tidak melaksanakan program PUS-nya hanya karena ketiadaan dana. Kerjasama internasional di dalam meningkatkan upaya keaksaraan khususnya, pelaksanaan PUS umumnya perlu diperkuat menuju dunia yang bebas buta huruf!

\section{CATATAN}

1 EFA Global Monitoring Report 2006, LITERACY FOR LIFE, a Team Report to UNESCO. Paris: UNESCO Publishing, 2005.

2 HIV = Human Immunodeficiency Virus - Virus yang Membuat Kekurangkebalan Manusia; AIDS =Acquired Immune Deficiency Syndrome - Sindrom Kekurang-kebalan yang Diperoleh.

3 Delors, Jacques (Chairman), International Commission on Education for the Twenty-First Century, Report to UNESCO: "LEARNING: THE
TREASURE WITHIN“. Paris: UNESCO Publishing, 1996.

4 Covey, Stephen R. THE SEVEN HABITS OF HIGHLY EFFECTIVE PEOPLE. New York: Simon \& Schuster, 1989; sudah diterjemahkan ke dalam bahasa Indonesia oleh Sdr. Drs. Budijanto, TUJUH KEBIASAAN MANUSIA YANG PALING EFEKTIF: (1) Jadilah proaktif (proactive); (2) Perhatikan tujuan yang akan diraih (keep the end in mind); (3) Ambeg parama arta atau memprioritaskan (prioritizing); (4) Menang-menang (win-win); (5) Memahami dulu 
barulah dipahami (first to understand then to be understood); (6) Gotong-royong (synergy); dan (7) Asahlah gergaji (sharpen the saw); dan Stephen R. Covey, THE $8^{\text {th }}$ HABIT, Melampaui Efektivitas, Menggapai Keagungan: pemimpin adalah panutan, perintis, penyelaras, dan pemberdaya. Jakarta: PT Gramedia Pustaka Utama, 2005.

5 Dryden, Gordon and Dr. Jeannette Vos, THE
LEARNING REVOLUTION. Torrance, CA, USA and Auckland, New Zealand: The Learning Web, 1999; sudah diterjemahkan ke dalam bahasa Indonesia.

6 Napitupulu, W. P. DIMENSI-DIMENSI PENDIDIKAN. Jakarta: BPK Gunung Mulia, 1967.

7 EFA Global Monitoring Report 2006, LITERACY FOR LIFE, Report to UNESCO. Paris: UNESCO Publishing, 2005.

\section{DAFTAR PUSTAKA}

Covey, S.R. (1989). The Seven habits of highly effective people. New York: Simon \& Schuster.

Covey, S.R. (2005) .The $8^{\text {th }}$ habits, melampaui efektivitas, menggapai keagungan. Jakarta: Gramedia Pustaka Utama.

Delors, J. (Chairman). (1996). Learning: The Treasure within.International Commission on Education for the Twenty-First Century, Report to UNESCO. Paris: UNESCO Publishing.
Dryden, G. \& Vos, J. (1999). The learning revolution. Torrance, CA, USA and Auckland, New Zealand: The Learning Web.

Napitupulu, W.P. (1967). Dimensi-dimensi pendidikan. Jakarta: BPK Gunung Mulia.

UNESCO. (2005). EFA Global Monitoring Report 2006, Literacy for Life, a Team Report to UNESCO, Paris: UNESCO Publishing, 2005. 